\title{
De novo design of molecular wires with optimal properties for solar energy conversion
}

\author{
Noel M O'Boyle ${ }^{1 *}$, Casey M Campbell ${ }^{2}$, Geoffrey R Hutchison ${ }^{2}$ \\ From 6th German Conference on Chemoinformatics, GCC 2010 \\ Goslar, Germany. 7-9 November 2010
}

The area of organic photovoltaic materials has elicited great interest in both the scientific and technological communities due to its potential to deliver cheap and highly efficient solar cells [1]. To date, however, such so-called molecular wires have typically yielded energy conversion efficiencies of only $\sim 5-6 \%$ despite a theoretical maximum of $13 \%$ [2].

We present an approach that uses a genetic algorithm to search the space of synthetically accessible molecular wires for those with optimal electronic structures. This approach combines both cheminformatics (SMILES to 3D using OpenBabel) and computational chemistry (semi-empirical calculations using Gaussian09). Using this method, we have found hundreds of candidates with predicted efficiencies over $8 \%$ including many with efficiencies over $10 \%$.

\author{
Author details \\ ${ }^{1}$ Analytical and Biological Chemistry Research Facility, University College \\ Cork, Cork, Ireland. 'Department of Chemistry, University of Pittsburgh, 219 \\ Parkman Avenue, Pittsburgh, Pennsylvania 15260, USA. \\ Published: 19 April 2011 \\ References \\ 1. Gunes S, Neugebauer H, Sariciftci NS: Conjugated polymer-based organic \\ solar cells. Chem. Rev. 2007, 107:1324-1338. \\ 2. Scharber M, Wuhlbacher D, Koppe M, Denk P, Waldauf C, Heeger A \\ Brabec C: Design rules for donors in bulk-heterojunction solar cells - \\ Towards 10\% energy-conversion efficiency. Adv. Mater. 2006, 18:789-794. \\ doi:10.1186/1758-2946-3-S1-014 \\ Cite this article as: O'Boyle et al:: De novo design of molecular wires \\ with optimal properties for solar energy conversion. Journal of \\ Cheminformatics 2011 3(Suppl 1):014.
}

\footnotetext{
* Correspondence: n.oboyle@ucc.ie

${ }^{1}$ Analytical and Biological Chemistry Research Facility, University College Cork, Cork, Ireland

Full list of author information is available at the end of the article
}

\footnotetext{
Publish with ChemistryCentral and every scientist can read your work free of charge

"Open access provides opportunities to our colleagues in other parts of the globe, by allowing anyone to view the content free of charge."

W. Jeffery Hurst, The Hershey Company.

- available free of charge to the entire scientific community

- peer reviewed and published immediately upon acceptance

- cited in PubMed and archived on PubMed Central

- yours - you keep the copyright

Submit your manuscript here:

http://www.chemistrycentral.com/manuscript/

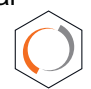

Chemistry Central
}

\section{(O) Chemistry Central}

